\title{
Comparative efficiency of applying heat pumps within the system of disposal of the condensation heat of heat machines for heating ice arenas
}

\author{
Aleksey Kondrashov ${ }^{1, *}$, Mikle Egorov ${ }^{1,2}$, Ivan Kovalenko², Nadezhda Litvinova², Natal'ya Lavrovskaya ${ }^{2}$ and \\ Irina Krectunova ${ }^{2}$ \\ ${ }^{1}$ Peter the Great St.Petersburg Polytechnic University, St. Petersburg, 195251, Russia \\ ${ }^{2}$ St. Petersburg State University of Aerospace Instrumentation, St. Petersburg, 190000, Russia
}

\begin{abstract}
The analysis of the application of two energy-efficient technologies for air heating of ice arenas is considered, such as the use of heat pumps and a system for partial utilization of heat of condensation of heat engines. The actual energy costs during the operation of two systems are studied, such as the consumption of heat and electricity from heat and power supply organizations, as well as the costs of modernization. The weaknesses and positive aspects of the studied systems for air heating of ice arenas are revealed. Comparison of the calculated data obtained as a result of calculations with the actual data obtained in the research institution in which the study is carried out. An example of actual effective modernization of existing engineering systems is shown, as a result of which the energy efficiency of existing systems is increased. Additionally, we have performed the calculation of reducing thermal pollution with introduction of the investigated systems.
\end{abstract}

\section{Introduction}

Currently, due to the constant increase in energy prices in the territory of the Russian Federation, the direction of energy conservation is actively developing, tasks are being set to reduce heating costs by introducing energyefficient solutions [1-11].

One of the most popular ways to use environmental energy (soil, water, air) is to use a heat pump (VT). The concept of the operation of the VT is based on the collection of low potential energy and its use, both for heating, ventilation, and for heating water for household needs [12].

In addition, in some cases, it is economically profitable for enterprises to upgrade existing technological equipment to increase the energy efficiency of engineering systems, which in most cases is selected with a margin $[13,14]$. One of these methods of energy saving is the utilization of heat generated during various technological processes, and the use of this heat energy for the needs of the consumer [15-18]. Currently, heat recovery and the use of renewable energy sources in microclimate systems are widely used in the air system heating [19-21].

\section{Methods}

The object of the study is the heating of ice arenas in St. Petersburg State University of Higher Education SSHR in figure skating (Fig. 1) with a heat pump and an integrated system for the partial utilization of the heat of condensation of heat engines.

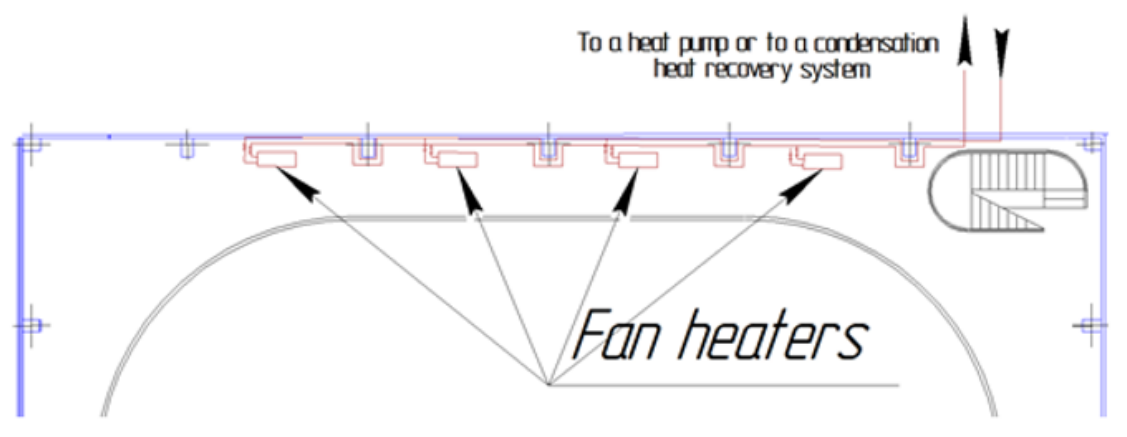

Fig. 1. Ice arena. Fan heaters for air heating.

\footnotetext{
* Corresponding author: akondrasha@mail.ru
} 
The purpose of the work is to identify problems associated with the overexpenditure of energy spent on maintaining the microclimate in sports facilities with artificial freezing of the ice surface, and ways to solve them. The relevance of the issue is due to economic and environmental aspects. A general analysis of existing technologies and examples of the implementation of these technologies at sports facilities are carried out. New schemes for organizing heating and ways to reduce costs are proposed. The positive effect and design conditions for achieving energy conservation goals are described. Further ways of developing heating and ventilation systems are proposed.

The objective of the work is to determine an economically and energetically advantageous solution by carrying out appropriate calculations and measurements of the use of a heat pump and a system for utilizing the heat of condensation of heat machines for heating ice arenas [22].

In the work, an actual study of the use of a heat pump and the introduction of a system for utilizing the heat of condensation of heat engines during air heating of ice arenas were carried out (Fig. 2).

\section{Equipment:}

The institution in which the study is performed: SPB GBU SSHR Figure Skating, located at St. Petersburg, ul. Tupolevskaya, building 4
- Three ice arenas (2 arenas - 30x60 sq.m. (fig.2) and 1 arena 20x24 sq.m. (fig.3), total area 4100 sq.m.)

- Three chillers BE / SMED-BT2402 manufactured by Climaveneta, each of which includes two semihermetic screw compressors Bitzer CSH 8571-140Y40D, with a total cooling capacity of $900 \mathrm{~kW}$

- Three air condensers FRIGA-BOHN ECA08P9 P10C3

- Six forks Alfa Laval CPS / S 145

- Wilo IL50 / 170-7.2 / 2 loop circulation pump

- Twenty fan heaters VEABA W61

- Heat pump SRAN-R-SL 1202 manufactured by Climaveneta, with a heating capacity of $357 \mathrm{~kW}$.

In the institution where the study was conducted, before the implementation of the system for utilizing the heat of condensation of heat engines, the heating of ice arenas was divided into two stages

- heating and

- inter-heating.

During the heating period, ice arenas were heated due to the heat supplied from the heat supply organization, and in the interheating due to the heat pump.

Currently, only the system for utilizing the heat of condensation of heat engines is constantly involved in the heating of ice arenas.

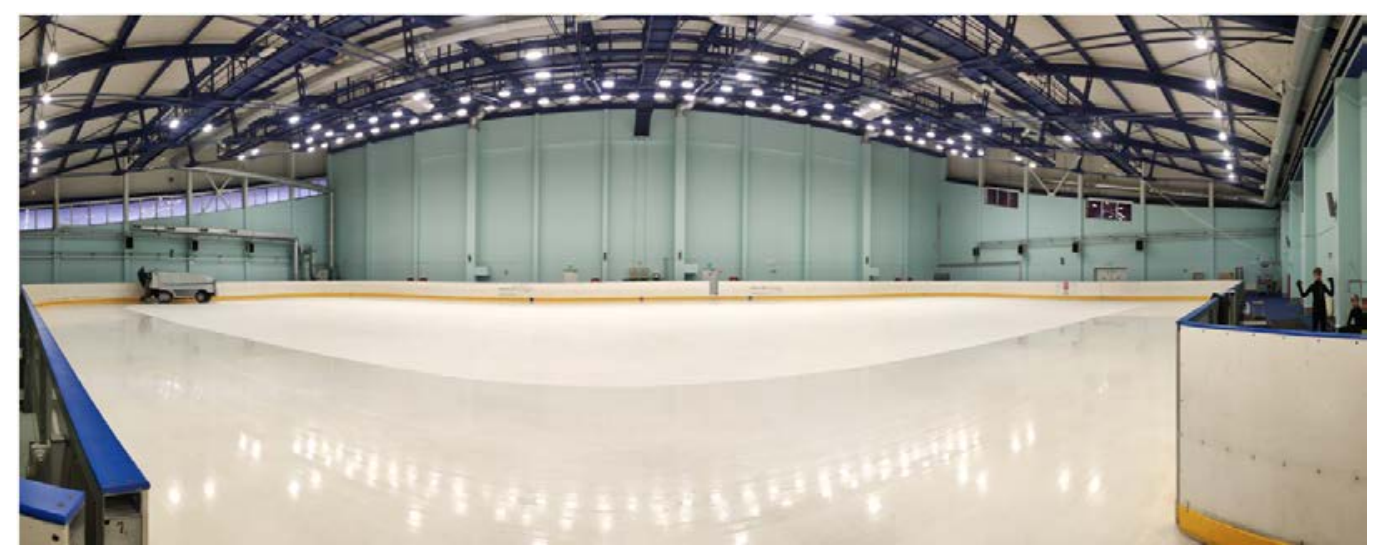

Fig. 2. Training ice arena.

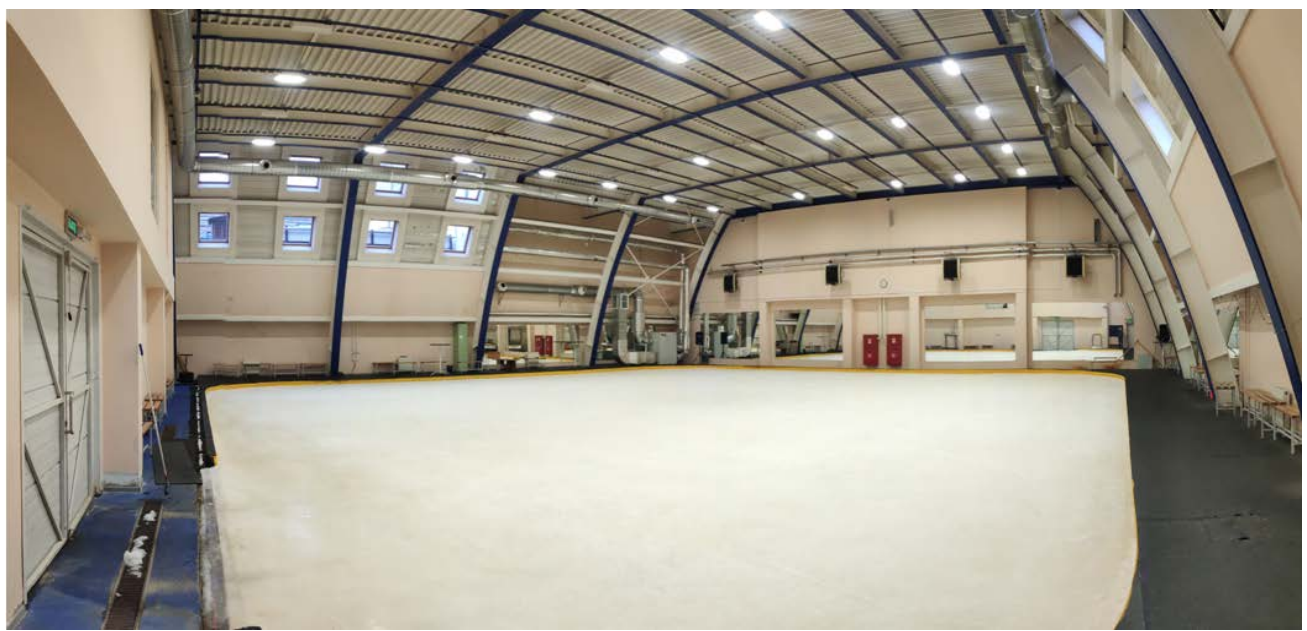

Fig. 3. Small ice arena. 
Table 1. Comparison of calculated and actual data.

\begin{tabular}{|c|c|c|}
\hline Naming of expenditures & $\begin{array}{c}\text { Costs determined by } \\
\text { calculation }\end{array}$ & Actual costs \\
\hline $\begin{array}{c}\text { Payment for consumed Gkall heat supply } \\
\text { organization, for 7 months }\end{array}$ & 1650000 rubles. & 1235654 rubles. \\
\hline $\begin{array}{c}\text { Payment for electricity consumed during } \\
\text { the operation of the heat pump, for 5 months }\end{array}$ & 684064 rubles. & 1225565 rubles. \\
\hline $\begin{array}{c}\text { The difference between the calculated } \\
\text { values and the actual, rubles. }\end{array}$ & 2334064 rubles. & 2461219 rubles. \\
\hline
\end{tabular}

\section{Results and Discussion}

When using a heat pump, the cost of operating costs for 5 months will be 684064 rubles.

When using only the heat recovery system of condensation of heat engines for the same period, the cost of operating costs will be 162049 rubles. (Fig. 4).

- Heat pump

- System for utilizing the heat of condensation of heat engines

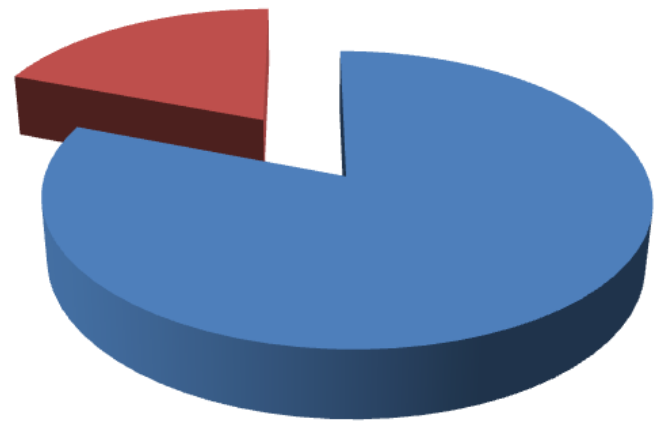

Fig. 4. Operating costs of systems, rub.

As a result, when comparing operating costs during operation of a heat pump and a system for utilizing the heat of condensation of heat engines, a cost-effective solution in this study case is a system for utilizing the heat of condensation of heat engines, the savings over 5 months will amount to $684064-162049 \approx 522015$ rubles or 104403 rubles/month.

The above results indicate the calculated values determined by the formulas, actual measurements confirmed the indicated amounts of expenses, a comparison of which is shown in table 1.

\section{Conclusions}

The introduction of a system for partial utilization of condensation heat of refrigeration machines for heating ice arenas due to fan heaters showed the following savings:

1. If you refuse the heat supplied by the State Unitary Enterprise TEK for heating the heat carrier for ice arena fan heaters in favor of using the condensation heat recovery system of refrigeration machines, taking into account the costs of the actual implementation, we will save about 2 million rubles in year:

$$
\begin{gathered}
\mathrm{C}_{\text {total savings }}=\mathrm{C}_{\text {annual heat effect }}+\mathrm{C}_{\text {savings on rejecting a heat pump }}- \\
-\mathrm{C}_{\text {syst. oper. costs. }}-\mathrm{C}_{\text {syst. installation costs }} \\
\mathrm{C}_{\text {total savings. }}=1,65 \mathrm{mln} . \text { rub. }+684064 \text { rub. }- \\
-177350 \text { rub. }-115131,42 \text { rub. } \approx 2 \mathrm{mln} . \mathrm{rub} . / \text { year }
\end{gathered}
$$

2. Reduction of thermal pollution of St. Petersburg from the Institution by no less than $1746360 \mathrm{~kW}$ per year.

\section{References}

1. Polyakova V. Yu., Kalinina T.O., Kichin K.V.: Anal. of energy eff. of heat pumps in heat supply sys. based on terr. and clim. char. Young Scientist 27, 142-146 (2016).

2. Russian Federation. The laws. On en. saving and on impr. energy eff. and on amen. certain leg. acts of the R.F. of Nov. 23. 261-FZ (2009).

3. Vilinskaya A.O., Nemova D.V., Davydova E.I., Gnam P.A.: Rising the energy. Eff. class of public building. Constr. of Unique Buildings and Structures 9 (36), 7-17 (2015).

4. Kiryudcheva A.E., Shishkina V.V.: Energyefficient façade syst. Constr. of Unique Buildings and Struct 4 (31), 248-262 (2015).

5. Gorshkov A.S., Rakova K.M., Musorina T.A., Tseytin D.N., Agishev K.N.: Building proj. with low cons. of thermal energy for heating. Constr. of Unique Buildings and Structures 4 (31), 232-247 (2015).

6. Kurochkina K.Yu., Gorshkov A.S.: Inf. of aut. control on the power cons. of resid. buildings. Constr. of Unique Buildings and Structures 4 (31), 220-231 (2015).

7. Gubina I.A., Gorshkov A.S.: Energy saving in buildings with heat rec. exhaust air. Constr. of Unique Buildings and Structures 4 (31), 209-219 (2015).

8. Zadvinskaya T.O., Gorshkov A.S.: Method of energy eff. of resid. house by impl. of aut. contr. heat metering syst.. Constr. of Unique Buildings and Structures 8 (23), 79-92 (2014). 
9. Nemova D.V.. Ventil. Syst. in residential buildings as a means of impr. energy efficiency. Constr. of Unique Buildings and Structures 3(3), 83-86 (2012).

10. Avsiukevich A. D.: Energy efficiency and energy sav. in heat supply systems. Const. of Unique Build. and Struct 2 (7), 40-54 (2013).

11. Shuravina D.M., Fokina N.B., Averyanova O.V.: Compr. heat pumps as an energy eff. devices. Constr. of Unique Buildings and Structures 10 (15), 62-76 (2013).

12. Nedviga P.N.: Possib. of using heat accum. and low-grade heat of the earth when heating individual houses. Engin. and Constr. Journal 3, 1-6 (2010).

13. Simbirev O.V.: Prosp. for the modern. of heating and ventil. syst. of buildings. Colloq.-journal 13-2 (37), 207-208 (2019).

14. Sibikin Yu. D.: Heating, ventil. and air condit. M., Academy (2007).

15. Minko V.A., Ilyina T.N., Potapova O.N.: Analysis of ways of recycling secondary heat from technol. equip. in the prod. shops of dairy plants. In: Bul. of BSTU named after V.G. Shukhov 4, 109-112 (2009).

16. Minko V.A., Kobelev N.S., Shchedrin P.Yu., Shchedrin G.G.: Feat. of heat transfer of air layers with internal curved grooves. In: Bull. of the Belg. State Technol. University. V.G. Shukhov 2, 149152 (2011).

17. Ilyina T.N., Feoktistov A.Yu., Mukhamedov R.Yu., Serikov S.V.: Ways of energy conserv. in microcl. syst.. Energy conserv. and ecol. in housing and com. serv. and urban constr. In: Intern. scientificpractical conf. Belg. gos. technol. University. pp. 244-248. Belgorod: Publishing House of BSTU (2012).

18. Ilyina T.N., Mukhamedov R.Yu., Serikov S.V. R.F. patent No. 2011108998, 07.27.2011. A dev. for energy rec. in the instal. of air condit. and ventil. Pat. of Rus. № 106938. Bull. No. 21 (2011).

19. Schukina T.V.: Develop. of technol. for incr. the energy activity of buildings with solar heat supply syst. Ind. and Civil Engin 2, 42-44 (2008).

20. Sotnikova O.A., Chudinov D.M., Schukina T.V.: Econ. rationale and prosp. for the dev. of solar heat supply. Indust. Energy 6, 50-52 (2008).

21. Kushchev L.A., Zolotukhin A.P., Savkin D.A.: The use of injection in a heat pump inst. to improve the energy efficiency of the system. In: Innov. mater. and techn. 1, pp.167-174, Belgorod: Publishing House of BSTU (2012).

22. Serikov S.V. Util. of heat from the flue gases of a boiler plant in an air heating syst. Bul. of the Belgorod State Techn. University. 4, 53-55 (2013) 